SANDA MILOŠEVIĆ

Hrvatski restauratorski zavod, Zagreb

smilosevic@h-r-z.hr

JELENA RANČIĆ

Gradski muzej Varaždin

jelena.rancic@gmv.hr
Primljeno: 21. 01. 2019.

Prihvaćeno: 06. 11. 2019.

DOI: $10.21857 /$ moxpjhg7pm

\title{
NOVI SJAJ KADŽARSKE KACIGE IZ GRADSKOG MUZEJA VARAŽDIN
}

Članak govori o restauraciji kadžarske kacige iz fundusa Gradskog muzeja Varaždin, provedenoj u Hrvatskom restauratorskom zavodu.

Kaciga je izrađena od damasciranog čelika, koftgari tehnikom. Suradnja djelatnika Gradskog muzeja Varaždin i Hrvatskog restauratorskog zavoda u istraživanjima i restauratorskom pristupu rezultirala je muzealnom prezentacijom kacige te definiranjem tehnika izrade, determiniranjem mjesta nastanka i datiranjem.

\section{UVOD}

Dugogodišnja suradnja Gradskog muzeja Varaždin i Hrvatskog restauratorskog zavoda oko očuvanja kulturnih dobara 2012. godine inicijativom muzejske savjetnice Spomenke Težak, voditeljice Zbirke militaria, proširena je i na Odjel za restauraciju metala, na kojem su provedeni konzervatorsko-restauratorski radovi na perzijskoj kacigi iz 19 . stoljeća. ${ }^{1}$

1 Inventarni broj kacige Gradskog muzeja Varaždin je GMV 62647, a u Hrvatskom restauratorskom zavodu 8007. 


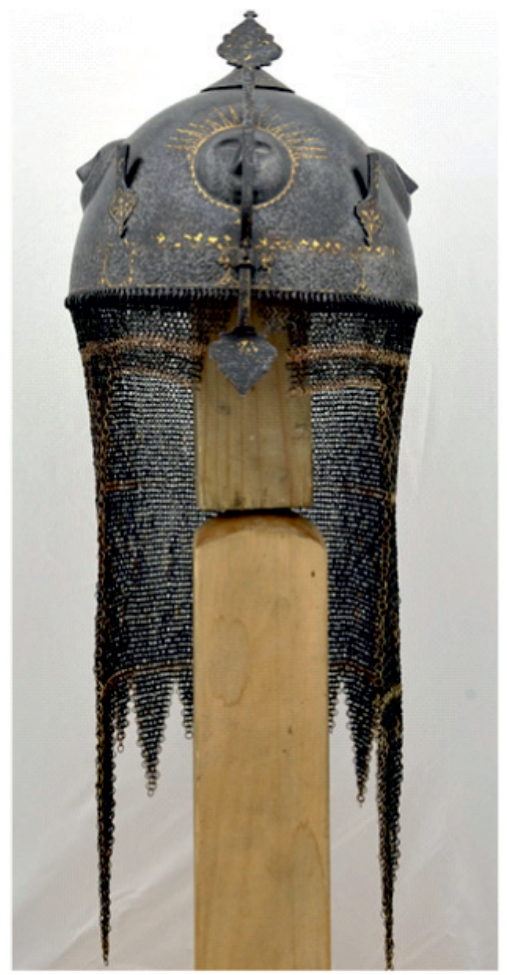

Slika 1. Kadžarska kaciga

Čelična kaciga, tzv. kolāhxud (kulah kud), izrađena za vrijeme dinastije Kadžar (1789. - 1925.), zaštićeno je kulturno dobro iz fundusa Povijesnog odjela Gradskog muzeja u Varaždinu. Kaciga je nerazjašnjene provenijencije, ali prema načinu izrade, vrsti materijala i dekorativnim elementima, činila je komplet s kružnim štitom inv. br. GMV 66636 i vjerojatno dvostrukom sjekirom inv. br. GMV 66637 iz stalnog postava Kulturnopovijesnog odjela muzeja. ${ }^{2}$ Kacige su bile dio ukupne ratničke opreme, a oklop ratnika uz kacigu činili su prsni oklop s če-

2 Kaciga je u vrijeme preuzimanja Zbirke militaria od strane muzejske savjetnice Spomenke Težak zatečena u muzeju bez inventarne oznake. S. Težak je za potrebe sređivanja i registracije Zbirke 2012. godine predmet inventirala i približno determinirala mjesto i vrijeme izrade. Pregledom postojeće i dostupne muzejske dokumentacije za sada nije utvrđeno vrijeme ulaska kacige u muzej, kao ni prethodni vlasnici. Na kacigi je nađen ostatak naljepnice s plavim obrubom, kakve je za obilježavanje predmeta koristio Krešimir Filić. Zbog političkih veza i diplomatskih funkcija te interesa za prikupljanje umjetnina, J. Rančić je sklona pretpostavci da je kaciga došla iz vlasništva obitelji Bombelles ili Paszthory-Varady. Obitelj Bombelles je od 1852. u posjedu dvorca Opeka, a obitelj od 19. st. PaszthoryVarady dvorca Križovljangrad. 
tiri ploče (čāhrāyne), štitnici za ruke (bāzuband), lančana bluza (zirah) te štitnici naziva jŏšan i garibān. Od oružja u manuskriptima spominju se luk (kamān), mač (shamšir), buzdovan (gorz), sjekira (tabar), koplje (neyze), štit (separ), nož (kard) i dr. ${ }^{3}$
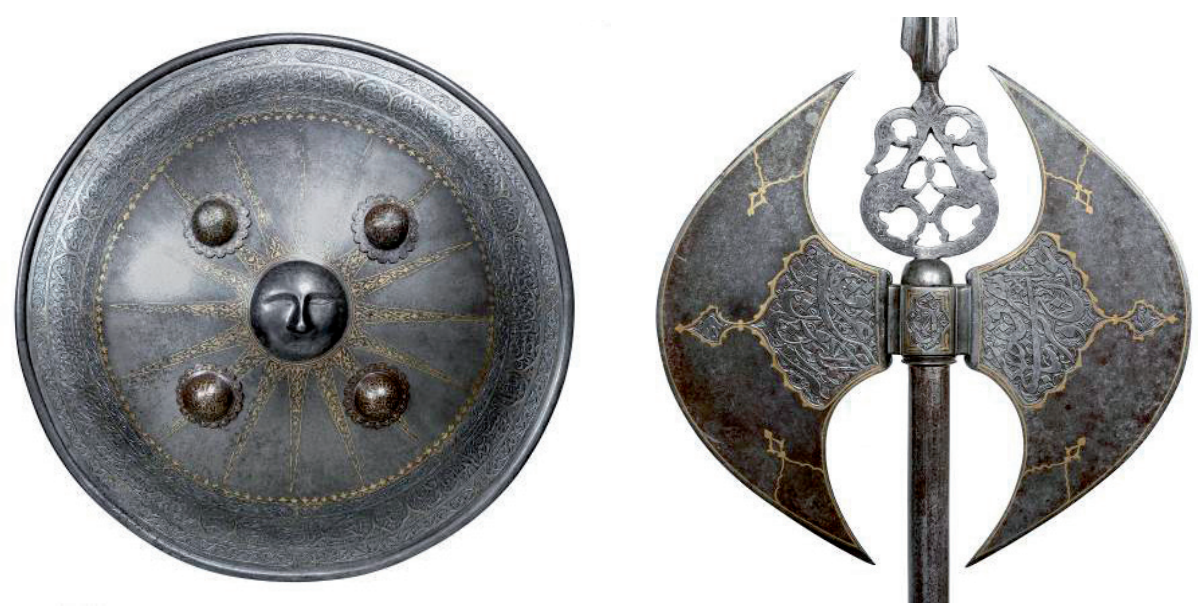

Slika 2. Kadžarski okrugli metalni štit, separ, inv. br. GMV 66636, bogato ukrašen iskucavanjem i tauširanjem u središtu sa izbočenim suncem s ljudskim licem i dvostruka sjekira, tabar, inv. br. GMV 66637

\section{O PERZIJSKIM KACIGAMA I NJIHOVOM UKRAŠAVANJU}

Pojavu ratničkih kaciga u Perziji pratimo od mongolske invazije u 13. stoljeću, a upravo je taj njen hemisferni oblik ostao isti tijekom narednih stoljeća. Već od 14. stoljeća kacige ovog tipa, pod nazivom kolāhxud, nalazimo u mnogobrojnim perzijskim manuskriptima na minijaturama. U Safidskom razdoblju (1501.-1722.) kacige se sastoje od dva dijela, konusnog komada koji pokriva glavu, izrađenu od tvrdog čelika i pletiva, mreže, sastavljene od metalnih karika koje štite vrat.

Kacige imaju štitnik za nos naziva damāqak, držače pera jāpari dok su se pera nazivala ablaq. Dva držača za perje na kacigi jako su stara i samo za Perziju karakteristična tradicija. Nakon poraza suparnika, pobjednik uzima pero s kacige poraženog kao trofej. Tkanina koja se postavljala s unutrašnje strane kacige

3 Manouchehr MOSFTAGH KHORASANI, Linguistic terms describing different types of armour in Persian manuscripts, XXXI GLADIUS (2011), 149-188. 
nazivala se aragchin i nerijetko je imala nekoliko slojeva, jer je osim zaštite glave upijala i znoj ratnika. ${ }^{4}$ Kacige su bile bogato ukrašavane ornamentom i natpisima. Dekorativnost kacige bila je gotovo jednako bitna kao i njezina namjena. Majstori koji su izrađivali ove kacige nazivali su se kolāhxudsāz, a korištene tehnike, materijali i dekorativni elementi na kacigama pokazuju iznimne sposobnosti majstora.

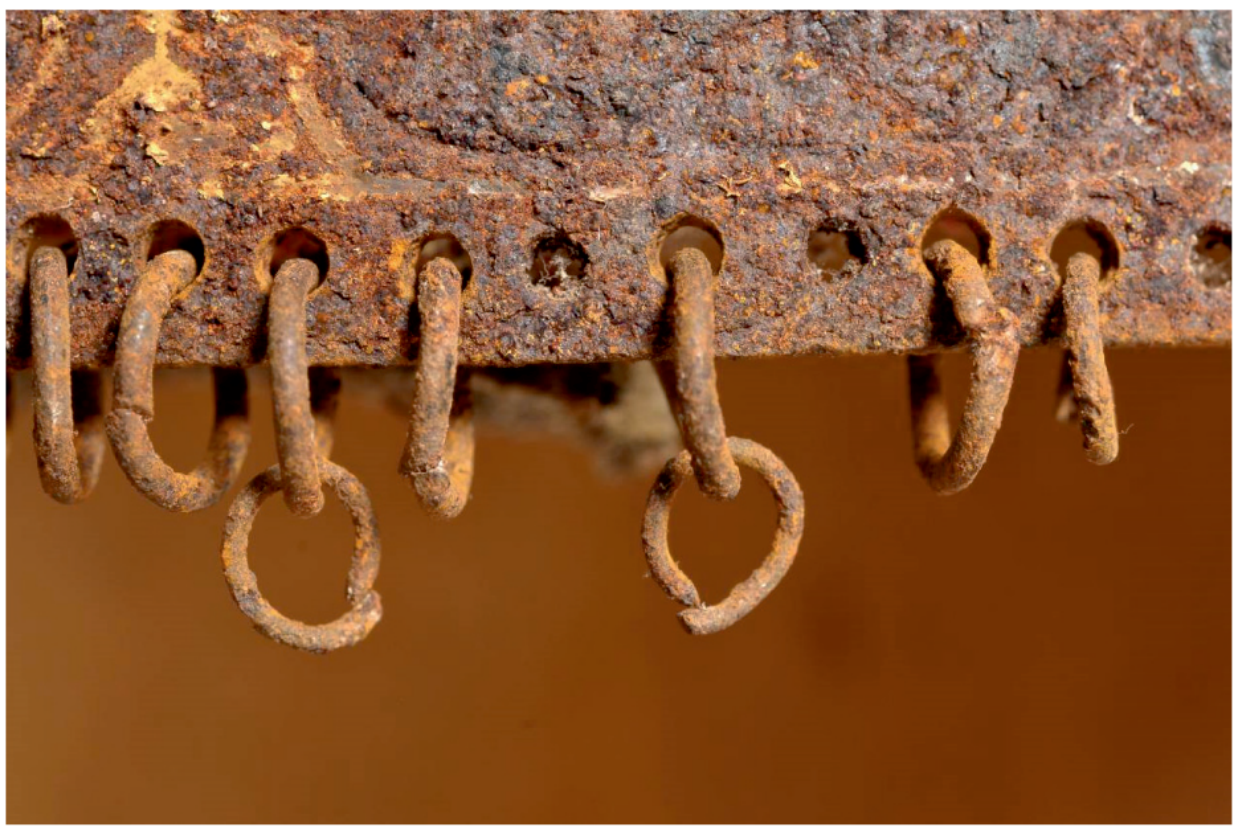

Slika 3. Obod kacige s karikama, detalj prije radova

Uobičajeno je da se tehnika ukrašavanja metalnih predmeta naziva tauširanje ili damasciranje. Osnovna površina od željeza, bakra, čelika ili nekog drugog metala, ukrašava se drugim metalom. Motiv se gravira raznim tehnikama, a potom se u gravuru ukiva neki od plemenitih metala. ${ }^{5}$ Tehnika je sam naziv damasciranje dobila po gradu Damasku zbog velike količine predmeta koji su tamo nastali i distribuirali se tijekom XVI. i XVII. stoljeća. ${ }^{6}$ Postoji nekoliko tehnika damasciranja, a jedna od njih je koftgari tehnika koja je bila primijenjena na ovoj

4 Isto, 165.

5 http://www.enciklopedija.hr/natuknica.aspx?id=68666 (5. 1. 2018.)

6 Ann FEUERBACH, "Damask, inlay and koftgari: A call for a definition of terms", History of ancient weapons Institute of History of Ukraine NASU, 2014., 242-251. 
kacigi. Koftgari tehnika bila je vrlo popularna na Istoku, a podrazumijeva umjetničku obradu na željeznim predmetima na način da se koloristički kontrastni metal umeće u udubljenja u osnovnom metalu. Postoji nekoliko različitih definicija što se koftgari tehnike tiče, ali kao osnovni metal najčešće se koristi čelik, bronca ili cinkova slitina, a umetci su najčešće od srebra, zlata ili mjedi. Površine koje se pokrivaju prvo su cizelirane, jetkane ili gravirane u željenom dizajnu, a zatim se zlato ili srebro utiskuje čekićem u utore. Površina se zatim uglađuje i na taj način se uklanja višak s površine, ostavljajući uzorak u utorima. Isti efekt može se postići blagim zagrijavanjem predmeta kako bi se metali sjedinili, a zatim bi se nakon hlađenja tauširani dio strugao, turpijao ili polirao. Prema analizi Feuerbach, postoje tri tipa koftgari tehnike i to plitki koftgari, lisnati koftgari i mrežasti koftgari. $\mathrm{Na}$ obodu kacige je primijenjen plitki koftgari. ${ }^{7}$

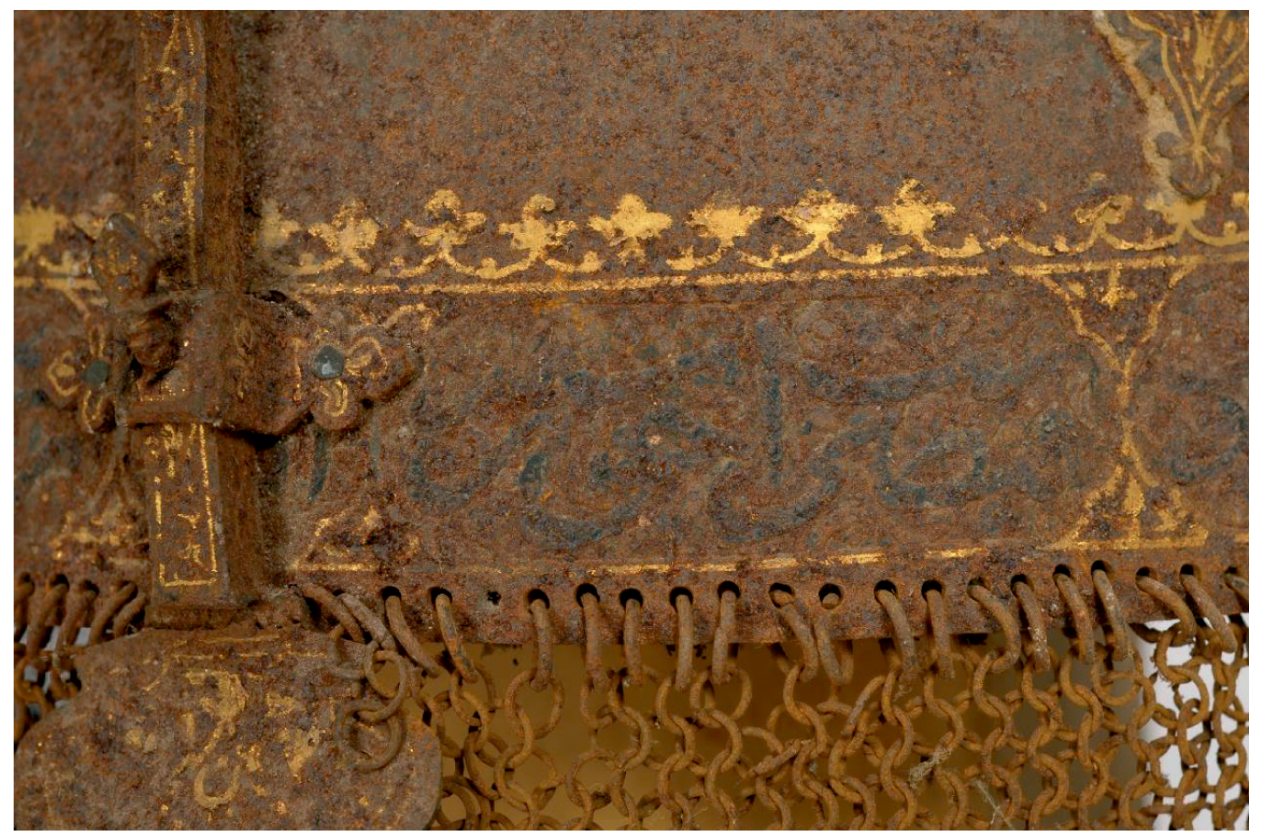

Slika 4. Obod kacige, detalj prije radova

7 Isto, 246. 


\section{KULTURNO - POVIJESNI ASPEKTI KADŽARSKE KACIGE IZ FUNDUSA GRADSKOG MUZEJA VARAŽDIN}

Kaciga iz varaždinskog muzeja polukuglastog je oblika, opsega (zajedno sa štitnikom za nos) $63 \mathrm{~cm}$, ima četiri reljefno istaknute ljudske maske u pravilnim razmacima koje su ukrašene tehnikom tauširanja u zlatu. Maske okružuju zrake izvedene u zlatu kako bi nalikovale prikazu Sunca. ${ }^{8}$ Sunce je uz Mjesec i nebo drevni perzijski simbol. Stihovi su gravirani u visini od $3 \mathrm{~cm}$ na obodu kacige te dodatno istaknuti zlatom, tehnikom damasciranja.

Na obod je mesinganim čavlićima pričvršćen utor kroz koji je provučen pomični držač za štitnik nosa. Krajevi držača s obje strane su stiliziranog lisnatog oblika, dodatno ukrašeni zlatom, tehnikom damasciranja. Iznad oboda, lijevo i desno od držača štitnika nalaze se iste lisnate aplikacije manjih dimenzija koje s gornje strane imaju cjevaste završetke koji su služili kao držači za perje. Kaciga u gornjem dijelu završava apliciranom spljoštenom formom stošca, koji je pričvršćen s 3 čavlića od mesinga, a vjerojatno je imala šiljak na vrhu koji, nažalost, nije sačuvan. Obod kacige ima ovješeno mrežno, lančano pletivo od čeličnih i mjedenih karika koje završavaju oblikom većih i manjih trokutastih šiljaka. Pletivo je složeno na tzv. četiri u jedan način od nezakovanih čeličnih karika, a služilo je kao zaštita bočnih strana lica i vrata ratnika. Među čelične dodane su mjedene karike i na taj je način pletivu dana dodatna dekorativnost. S unutrašnje strane kacige postavljena je tkanina.

Natpis na obodu kacige na perzijskom je jeziku, zapisan perzijskim pismom. ${ }^{9}$ Natpis nije u cijelosti preveden, no na osnovi prevedenih riječi i sintagmi može se zaključiti da je tekst motivacijskog karaktera, čija je zadaća podizanje borbenog morala vojnika. Navođenje imena Alija (četvrtog sunitskog halife i prvog šijitskog imama), kao i riječi „istina“ i „laž“, ukazuje na to da natpis sadrži i jasne ideološke konotacije, to jest odražava odnos konfrontacije između sunitskog i šijitskog islama. Na ratničkim kacigama u vrijeme Safavida i Kadžara (obje su bile izrazito rigidne šijitske dinastije i nerijetko u sukobu sa susjednim sunitskim kraljevinama) navođene su rečenice poput: nu nećeš pronaći (spoznati) osim s Alijem“, to jest „Istinu ćeš pronaći (spoznati) samo s Alijem/slijedeći Alija". ${ }^{10}$

Komparativna analiza ukazuje na perzijsku provenijenciju i datiranje u vrijeme Kadžara, turkmenske dinastije, koja je vladala Perzijom od 1796. do 1925.

\footnotetext{
Identično reljefno lice sa zrakama nalazi se u središtu štita, inv. br. GMV 66636.

9 Perzijsko pismo je, u osnovi, arapsko pismo prilagođeno fonetskim značajkama perzijskog jezika.

10 Na prijevodu i interpretaciji natpisa zahvaljujemo prof. dr. Namiru Karahaliloviću.
} 
godine. ${ }^{11}$ Način spajanja čeličnih karika, koje nisu spajane zakovično, što je tipično za 18. stoljeće, već su im rubovi samo stisnuti jedan do drugog idu u prilog dataciji kacige u 19. stoljeće. ${ }^{12} \mathrm{U}$ devetnaestom stoljeću dolazi do modernizacije iranske vojske, no tradicionalni oklopi i dalje se proizvode te koriste u vojnim povorkama, kao kostimi nose u dramatizacijama, ili prodaju ili daruju kao skupocjeni suveniri za europsko tržište. ${ }^{13}$

Namjena kacige iz Gradskog muzeja Varaždin vjerojatnije je bila prije reprezentativna ili ritualna nego ratna, čemu u prilog ide i vrijeme nastanka i sadržaj teksta na obodu, a možda je korištena kao dio kostima u dramskom prikazu bitke kod Karbale u sklopu šijitske pasijske igre ta'ziyeh. ${ }^{14} \mathrm{U}$ bitci kod Karbale 680. godine n. e., ubijen je Husejn ibn Alija, Muhamedov unuk sa svojih 72 pristaša i sljedbenika, uključujući i njegova šestomjesečnog sina. Huseinova strast i smrt smatraju se krajnjim primjerom žrtve za šijitske muslimane, koji bitku kod Karbale i mučeništvo Alija obilježavaju svake godine tijekom desetodnevnog perioda mjeseca Muharram i praznikom Ašurom. Na taj se dan odvijaju mučeničke procesije, recitiraju religijski tekstovi, te se oživljava sama bitka. Glumci su odjeveni u tradicionalne kostime, nose ratničke oklope i oružje poznato od kasnog srednjovjekovlja. ${ }^{15}$ Suniti se od šijita razlikuju bojom: nose crvene detalje (poput pera na kacigama), koji simboliziraju krv i ugnjetavanje, dok šijiti nose zelenu

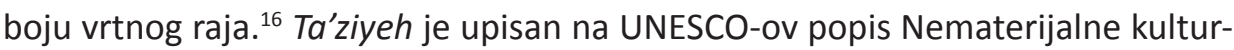
ne baštine čovječanstva 2010. godine. ${ }^{17}$ Igrani prikazi bitke počeli su se izvoditi neposredno nakon same bitke kod Karbale, proširili su se tijekom safavidske vla-

11 Za komparativnu analizu korištena je građa prvenstveno iz objavljene literature, a sekundarno izvorima s internetskih aukcijskih kataloga i zbirki. Autorice su varaždinsku kacigu komparirale i s kadžarskim kacigama viđenim prilikom posjeta muzeju u Českýom Krumlovu, milanskom muzeju Poldi Pezzoli i danskom Davids Samlingu u Kopenhagenu. Pregledavane online aukcijske kuće i zbirke su: Hermann Historica, Christie's, Sotheby's, Dorotheum, The Jorge Caravana Collection i dr., kacige na online stranicama The Metropolitan Museum of Art inv. br. 02.5.7 i 36.25.16, The British Museum inv. br. 1878,1230.772 i dr.

12 O dataciji mrežnog pletiva vidi: Filiz Çakir PHILLIP, Iranische Hieb-, Stich- und Schutzwaffen des 15. bis 19. Jahrhunderts: Die Sammlungen des Museums für Islamische Kunst der Staatlichen Museen zu Berlin und des Deutschen Historischen Museums (Zeughaus) in Berlin, Walter de Gruyter GmbH \& Co KG, 2015., str. 66.

13 Isto, 66.

14 Peter J. CHELKOWSKI, „Ta'ziyeh: Indigenous Avant-Garde Theatre of Iran“, Performing Arts Journal, Vol. 2, No. 1, 1977., str. 31-40.

15 Manouchehr MOSFTAGH KHORASANI, Passion play (Ta'zyeh), u: Thomas A. GREEN, Martial Arts of the World - An Encyclopedia of History and Innovation, 2010., str. 367-8.

16 Peter J. CHELKOWSKI, Time Out of Memory: Ta'ziyeh, the Total Drama, https://asiasociety.org/timeout-memory-taziyeh-total-drama (10. 4. 2018.).

17 https://ich.unesco.org/en/RL/ritual-dramatic-art-of-taziye-00377 (10. 1. 2019.). 
davine, a pravi vrhunac i dramsku formu doživljavaju tijekom vladavine Kadžara, posebno u 19. stoljeću. Nasrudin-šah Kadžar (1831. - 1896.), umjetnosti sklon vladar, fotograf, slikar i pjesnik te prvi iranski monarh koji posjetio Europu, u Teheranu 1870. godine gradi Takia-ye Dawlat, Kraljevsko kazalište s 4000 mjesta. ${ }^{18}$ Do zabrane šaha Reze Pahlavija, u to je kazalište bio najpoznatiji izvođač ove forme religijskog epskog kazališta.

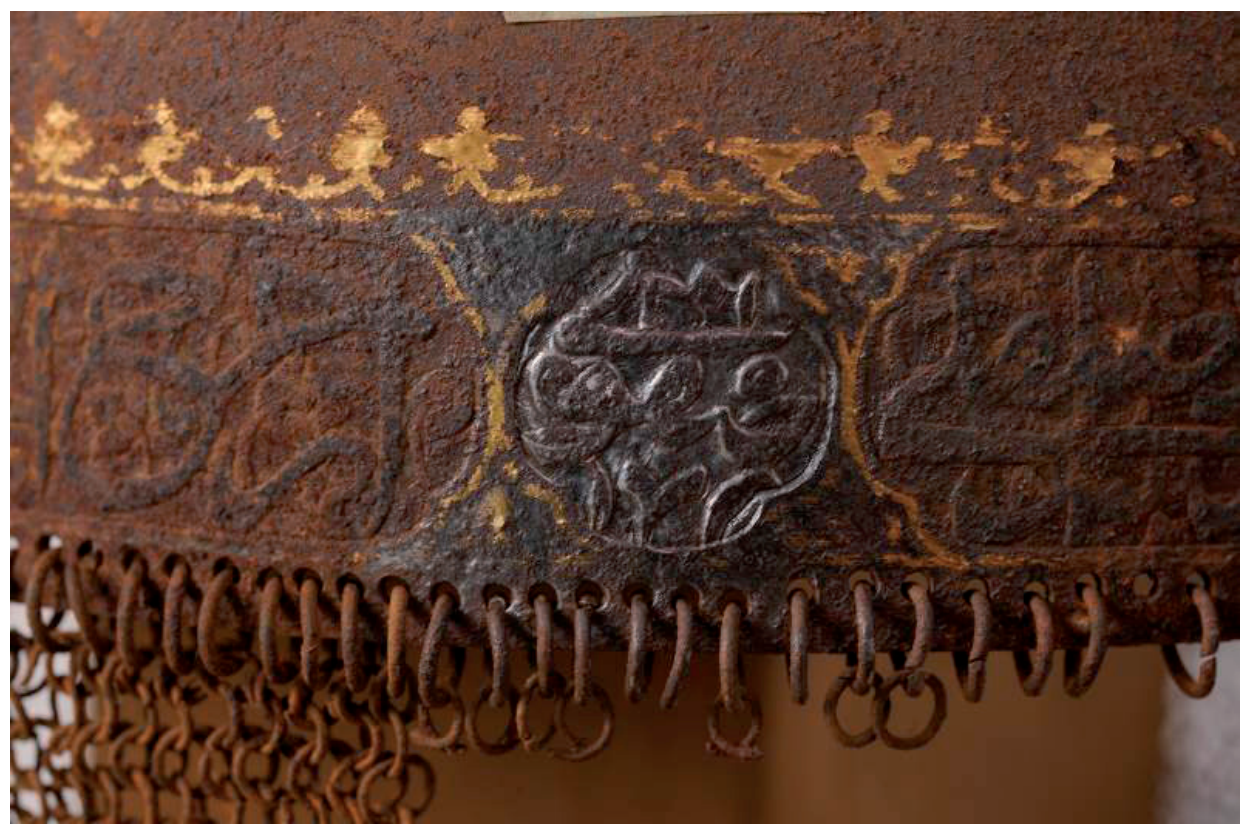

Slika 5. Obod kacige, detalj natpisa tijekom sondiranja.

\section{STANJE KACIGE PRIJE KONZERVATORSKO-RESTAURATORSKIH RADOVA}

Kaciga je prilikom preuzimanja iz Zbirke militaria zatečena u relativno lošem stanju, no prepoznata je njena stvarna vrijednost i potreba za konzervatorskorestauratorskim radovima.

18 Šah je Europu posjećivao u 1873., 1878. i 1889. godine, a putovao je od Kaspijskog mora do Rusije posjetivši Prusiju, Belgiju, Englesku, Francusku, Švicarsku, Austriju i Italiju. Naghmeh SOHRABI, Taken for Wonder: Nineteenth-Century Travel Accounts from Iran to Europe, Oxford University Press, 2012., str. 73-105. 
Oštećenja su nastala zbog čuvanja u neadekvatnim mikroklimatskim uvjetima sa visokom RH (i preko 65\%), dok je loša manipulacija i pohrana dovela do mehaničkih oštećenja karičastog pletiva ${ }^{19}$. Metalni dijelovi kacige bili su zahvaćeni korozijskim produktima, tako da je površina gotovo u cijelosti bila prekrivena jednolikim slojem smeđo - crvenkaste hrđe s vidljivim znakovima aktivne korozije. ${ }^{20}$ Hrđa se mjestimično trusila s površine u obliku narančaste prašine. Korozijski procesi uzrokovali su ohrapavljenje glatke metalne površine i smanjili čitljivost ukrasnih motiva i natpisa. Na tauširanim dijelovima došlo je i do kontaktne (galvanske) korozije. S obzirom da korozijski produkti imaju veći volumen od volumena uništenog metala došlo je do odizanja i gubitka dekoracija izvedenih u zlatu, kao i mjestimičnog nakupljanja hrđe preko zlata. Držač za nos nije bio pomičan zbog korozijskih produkata i s vremenom nataložene prašine, koja se u periodima povećane RH zalijepila na površinu. Strukturnih i dubinskih oštećenja kalote u smislu pukotina, lomova ili raslojavanja materijala nije bilo.

Karičasto pletivo se na stražnjem dijelu u većoj mjeri odvojilo od konusnog dijela kacige. Vezne karike većeg promjera uglavnom su ostale u konusnom dijelu kacige, dok je lančani preplet, sastavljen od karika manjeg promjera, ispao iz njih. Vidljivo je bilo nekoliko manjih perforacija, nastalih gubitkom karika, a na nekoliko mjesta pletivo se raspalo i izgubilo homogenost. Oštećenja pletiva bila su mehaničke prirode te su nastala kao posljedica ljudskoga djelovanja. Zbog loše manipulacije, višekratnog premještanja i loše pohrane karike su se deformirale, odvojile, ispale iz prepleta i s vremenom se izgubile. Površina svih karika bila je prekrivena korozijskim produktima. Na vrhu kacige nedostaje šiljak.

Podstava kacige (dimenzije 12 × $19 \mathrm{~cm}$ ) iskrojena je u obliku kape, od bijele i crvene pamučne tkanine, a između njih je sloj punjenja od pamučne vate. Vanjska tkanina platnenog tkanja je prirodne boje, dok je unutrašnja otkana u keper vezu crvene boje. Unutrašnja strana podstave obrubljena je ukrasnom trakom širine $1 \mathrm{~cm}$, a time je ujedno ojačan rub podstave. Traka je izrađena tehnikom preplitanja osnova različitih boja (svjetloplava, bijela, crna, ljubičasta), prugasta je po sredini, a na rubovima ima stupce s istkanim snopovima grančica.

19 Kaciga je nađena u sanduku u neizoliranom tavanskom prostoru Starog grada. Vlažnost zraka, kisik, kloridni ili drugi ioni, kisela sredina i viša temperatura ubrzavaju proces korozije željeza i nastajanje hrđe, hidratiziranog željezovog (III) oksida.

$20 \mathrm{Hrđa}$ je hidratizirani željezov (III) oksid $\left(\mathrm{Fe}_{2} \mathrm{O}_{3} \times \mathrm{nH}_{2} \mathrm{O}\right)$, no u širem smislu odnosi se na smjesu više različitih korozijskih produkata, oksida i oksihidroksida najčešće trovalentnog željeza. 


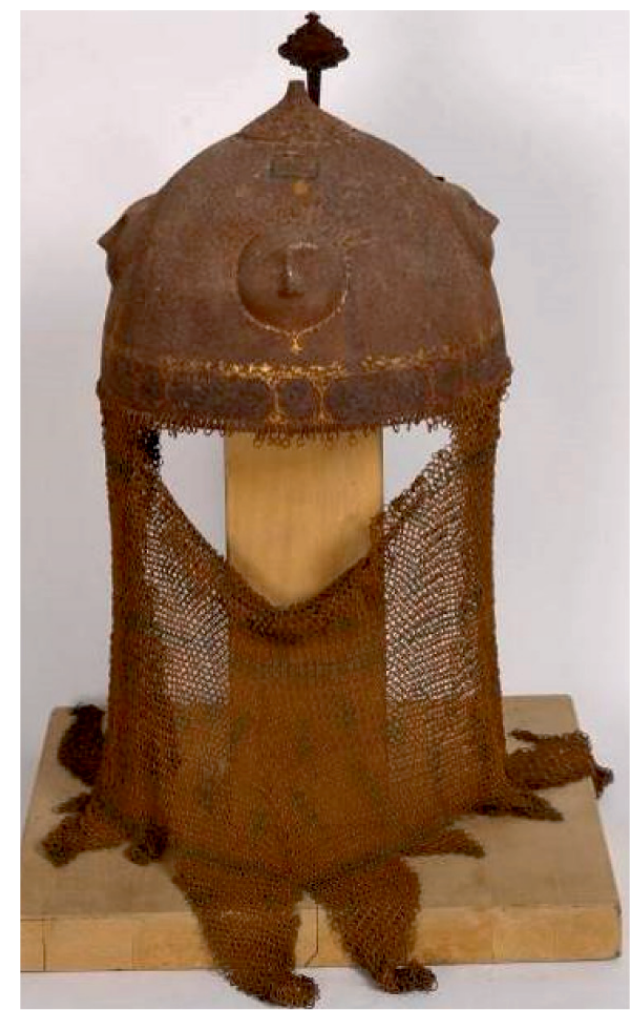

Slika 6. Kadžarska kaciga prije konzervatorsko-restauratorskih radova

\section{IZVEDENI KONZERVATORSKO-RESTAURATORSKI RADOVI}

Kaciga je prije počeka radova detaljno fotografski dokumentirana. Nakon preuzimanja kacige u Radionicu za metal HRZ-a, odvojena je unutrašnja podstava kako bi je mogle preuzeti djelatnice Odjela za tekstil HRZ-a. Laboratorijske analize metalnih dijelova nisu napravljene, nego je vrsta materijala, kao i korozijskih produkata determinirana iskustvom restauratora. $\mathrm{S}$ kacige je usisavačem s četkicama uklonjena površinska prašina te su na nekoliko mjesta napravljene sonde kako bi se odredio daljnji tijek radova. Sondiranjem je utvrđeno da se uz zlato pojavljuje i srebro, također izvedeno tehnikom damasciranja. ${ }^{21}$ Korozijski pro-

21 Prilikom određivanja tijeka konzervatorsko-restauratorskih radova, obavljene su konzultacije u suradnji s kustosicom Odjela S. Težak i ravnateljem M. Morandinijem te je zaključeno kako se izgubljeno zlato neće nadomještati jer je sačuvana količina dovoljna za vizualni dojam i muzejsku prezentaciju u postavu. 
dukti s kalote uklanjani su suhim mehaničkim postupkom, skalpelom, metalnim četkicama i kistovima, ručno pod povećanjem, uz povremeno pažljivo korištenje Antikorozina, kojim je pospješeno uklanjanje hrđe i ujedno stabiliziran metal. ${ }^{22}$ Zlato se u velikoj mjeri sačuvalo dok je srebro gotovo u potpunosti izgubljeno, a razlog tome je vjerojatno slabija kakvoća tog materijala. Karično pletivo odvojeno je od konusnog dijela kacige, rašireno i fiksirano za drvenu podlogu. Mehanički, kistovima i četkicama, uklonjeni su korozijski produkti. Karike deformirane mehaničkim uzrocima, ispravljene su i stisnute. One koje su nedostajale, kako čelične tako i mjedene, nadomještene su prema procjeni restauratora materijalima bliskom izvorniku. Nove karike od čelične žice patinirane su sumpornom jetrom, kako bi se izgledom uklopile u sačuvano pletivo te umetnute u pletivo prateći izvorni uzorak kako bi vizualni dojam ponovno bio potpun. Kaciga je dva puta premazana uljnim premazom, koji predmetu daje bolji izgled i istovremeno djeluje kao zaštitna barijera protiv vlage. ${ }^{23}$
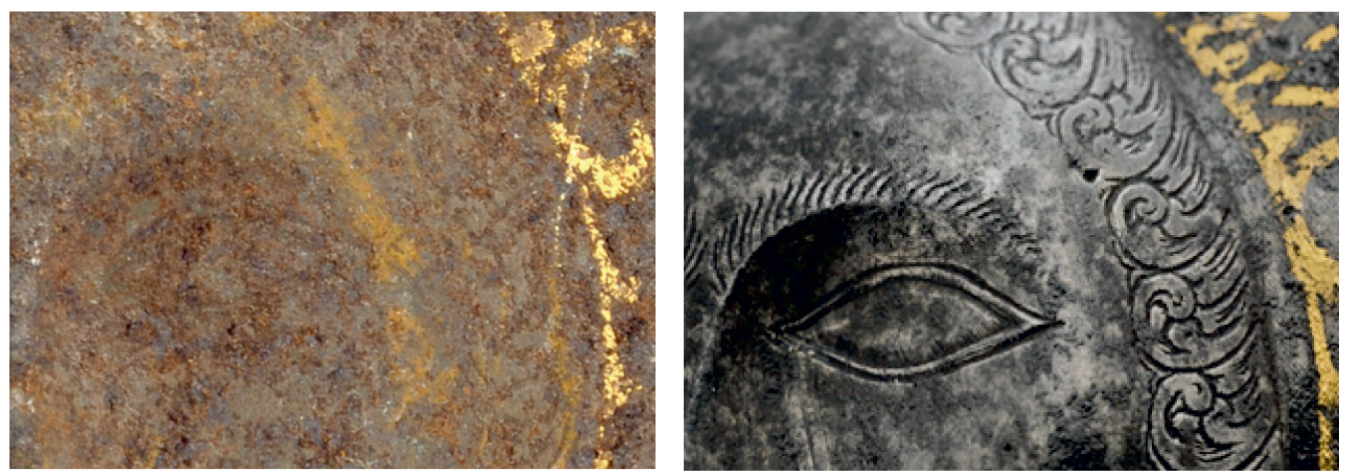

Slika 7. Detalj reljefno istaknute ljudske maske, detalj prije i nakon radova

Nakon odvajanja podstave od kacige, uočene su velike nakupine nečistoće, ostataka jajašaca, ličinki, hrđe te ostataka ljepila, a sve se to taložilo tijekom vremena u prostoru između kacige i podstave. Mikroskopskom analizom ustanovljeno je kako su crvena i bijela tkanina istkane nitima od pamučnih vlakana kao i vateno punjenje. Vezivo spoja podstave na kacigu i trakice na podstavi je miješanog sastava, jer je u uzrocima pronađeno proteinsko i saharidno vezivo s tragovima prirodne terpenske smole. Za analizu veziva provedena je tankoslojna

22 Antikorozin je komercijalno sredstvo za uklanjanje hrđe na bazi fosforne kiseline i tanina.

23 Uljni premaz, tvornički naziv Ballistol. 
kromatografija i FT-IR spektroskopija. ${ }^{24}$ Podstava je nakon odvajanja od kacige radi dezinsekcije stavljena u zamrzivač na 15 dana. Nakon dezinsekcije s tkanine je uklonjena prašina, jajašca insekati, paučina i druge nečistoće uz pomoć igala, pinceta, skalpela i medicinskog usisavača, preko zaštitne mrežice. Oštećenja glavne tkanine zatvorena su podlaganjem sličnom tkaninom i šivanjem tankim svilenim koncem dok su oštećenja na tkanini koja se nalaze između kacige i glavne tkanine prekrivena crepeline tkaninom. ${ }^{25}$ Ukrasna traka je lijepljenjem vraćena na odgovarajuće mjesto kako je i zatečena, upotrebom metilceluloznog ljepila Tylose. Podstava je vraćena u kacigu lijepljenjem linijski po donjem rubu, upotrebom Lascaux HV 498-20x koje ima sastav odgovarajućeg pH. Ovo ljepilo je odabrano jer kvalitetno spaja dva različita materijala i neće uzrokovati pojavu insekata ili plijesni. Ljepilo je reverzibilno, topivo u acetonu ili alkoholu. ${ }^{26}$

Kako bi se spriječila buduća mehanička oštećenja i spriječila korozija te taloženje prašine, kacigu je potrebno pohraniti u beskiselinskoj kutiji na nosaču koji omogućuje karičnom pletivu da visi bez preklapanja i gužvanja. U kutiju se može staviti suhi silika-gel, koji na sebe absorbira vlagu. Vlažnost u čuvaonici ne bi trebala prelaziti $40 \%$, a prilikom rukovanja kacigom, obavezno je nošenje rukavica.
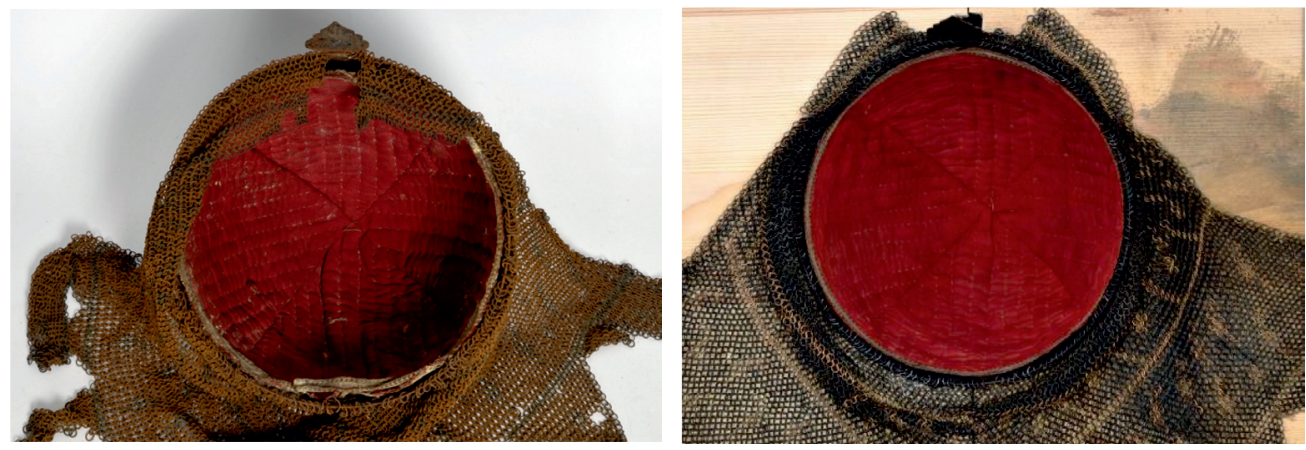

Slika 8. Unutrašnjost kacige s tekstilnom podstavom i pletivo, prije i nakon radova

Bez obzira na namjenu, bila ona ritualan, ratnički predmet ili suvenir, kaciga je izuzetno vrijedan i rijedak predmet, koji je novim sjajem zasjao nakon konzervatorsko-restauratorskih radova obavljenih u Hrvatskom restauratorskom zavo-

24 Laboratorijske analize tekstila i veziva: Margareta Klofutar, HRZ.

25 Konzervatorsko-restauratorski radovi na podstavi: Vlasta Bošnjak, Katija Hrepić, HRZ.

26 Konzervatorsko-restauratorski radovi na metalnim dijelovima kacige: Antonio Šerbetić, Ivan Fočić, HRZ. 
du. Uz same radove na kacigi, u sklopu konzervatorsko-restauratorskih istraživanja, provedena su povijesno-umjetnička istraživanja komparativnih materijala i literature koja su rezultirala i točnijom determinacijom vremena i mjesta nastanka samog predmeta.

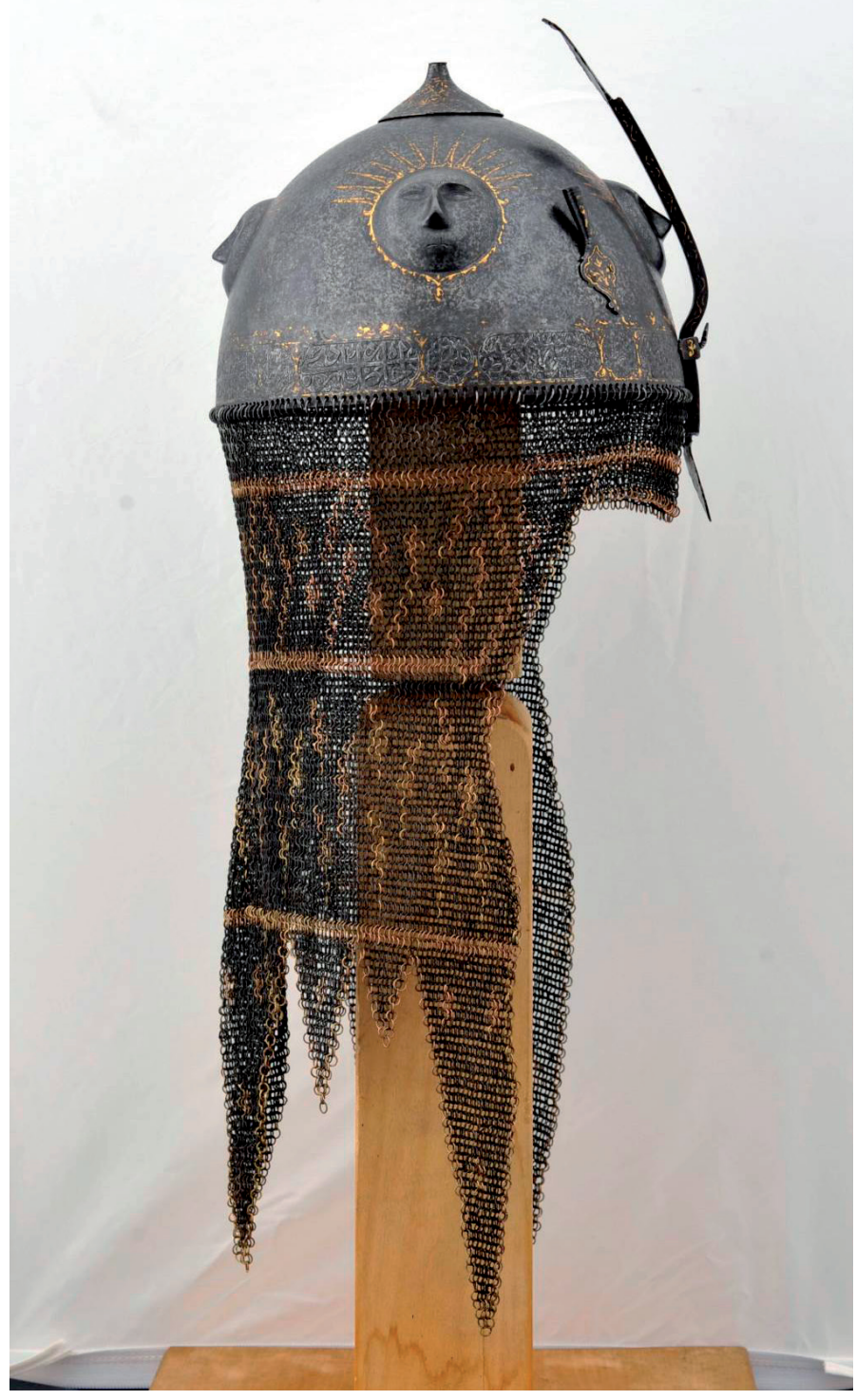

Slika 9. Kadžarska kaciga, nakon radova 


\section{LITERATURA}

1/ Peter J. CHELKOWSKI, „Ta'ziyeh: Indigenous Avant-Garde Theatre of Iran“, Performing Arts Journal, Vol. 2, No. 1, 1977., str. 31-40.

2/ Heather EMPEY, „The Shl'i Passion: Ta'ziyeh, Tragedy and the Sublime“, Institute of Islamic Studies McGill University, Montreal, 2003.

3/ Ann FEUERBACH, „Damask, inlay and koftgari: A call for a definition of terms“, History of ancient weapons Institute of History of Ukraine NASU, 2014., 242251.

4/ Çakir Phillip FILIZ, „Iranische Hieb-, Stich- und Schutzwaffen des 15. bis 19. Jahrhunderts", Die Sammlungen des Museums für Islamische Kunst der Staatlichen Museen zu Berlin und des Deutschen Historischen Museums (Zeughaus) in Berlin, Walter de Gruyter GmbH \& Co KG, 2015., str. 59-68.

5/ Thomas A. GREEN, Martial Arts of the World - An Encyclopedia of History and Innovation, 2010., str. 367-8.

6/ Manouchehr Moshtagh KHORASANI, Linguistic terms describing different types of armour in Persian manuscripts, 2011.

7/ Manouchehr Moshtagh KHORASANI, Arms and Armor from Iran: The Bronze Age to the End of the Qajar Period, Legat Verlag, 2006.

8/ Naghmeh SOHRABI, „Taken for Wonder: Nineteenth-Century Travel Accounts from Iran to Europe“, Oxford University Press, 2012., str. 73-105. 


\section{SAŽETAK}

\section{NOVI SJAJ KADŽARSKE KACIGE IZ GRADSKOG MUZEJA VARAŽDIN}

Kadžarska kaciga inv. br. GMV 2647 jedan je od mnogobrojnih predmeta koji svjedoče o dugogodišnjoj suradnji Gradskog muzeja Varaždin i Hrvatskog restauratorskog zavoda u brizi o očuvanju kulturnih dobara. Kaciga je izrađena od damasciranog čelika, konusnog oblika sa šiljkom na vrhu, koji nedostaje, dva utora za pera te lančanim štitnikom za vrat. Nepoznate je provenijencije, ali prema načinu izrade, vrsti materijala i dekorativnim elementima činila je komplet s kružnim štitom inv. br. GMV 66636 i vjerojatno dvostrukom sjekirom inv. br. GMV 66637. Prema načinu izrade i načinu spajanja lančanih zakovica, nastala je nakon sredine 19. stoljeća za vrijeme vladavine kadžarske dinastije. Namjena joj je vjerojatnije bila ritualna nego ratna, čemu u prilog ide vrijeme nastanka i sadržaj teksta na obodu, a korištena je možda u igranoj bitci u sklopu forme religijskog epskog kazališta Ta'ziyeh. Ovim se ritualom oživljava bitka kod Karbale iz 680. godine n. e., a šijiti je obilježavaju svake godine tijekom desetodnevnog perioda mjeseca Muharram. Konzervatorsko-restauratorski radovi obuhvatili su zaustavljanje procesa korozije u cijelosti, radove na tekstilu koji je služio kao podstava, nadomještanje karika u dugačkom pletivu duž oboda te zaštitu na kraju. Kaciga je primjer suradnje kustosa i restauratora oko konačne muzealne prezentacije predmeta. Odlučeno je kako ostaci sačuvanog zlata vizualno dobro funkcioniraju i nema potrebe za dodatnom intervencijom. Suradnja ovih dviju institucija dovela je do točnije datacije i determinacije samog predmeta.

Ključne riječi: kadžarska kaciga; kulah kud; restauracija; muzealna prezentacija 


\section{SUMMARY}

\section{NEW SHINE OF THE QUAJAR HELMET FROM VARAŽDIN CITY MUSEUM}

Quajar helmet is one of the many items that testify to the long-term cooperation between the Varaždin City Museum and the Croatian Conservation Institute in the care of cultural heritage. The helmet is made of steel, it has a conical shape, probably with a pointed spike on its top (unfortunately lost), two slots for feathers and a chain shield for the neck. Its provenance is unknown but according to the way of making, the type of material and decorative elements, it probably constituted a kit with a circular shield inv. no. GMV 66636 and double axe inv. no. GMV 66637. According to the way of making and the manner of joining the chain rivets, it was formed after the middle of the 19th century, under the rule of the Quajar dynasty. It was probably used in rituals rather than in wars, which is related to the time of creation and the content of the text on the rim, and it was maybe used in a played battle within the religious epic theatre Ta'zieh. This ritual revives the battle of 680s at Karbala, which Shiites mark every year during the ten-day period of Muharram. Conservation and restoration work included the elimination of corrosion process in its entirety, works on the textiles used as lining, the substitute of the links in knit band along the rim and the protection at the end. The helmet is an example of a curator and restaurateur's collaboration around the final museum presentation of the object. It was decided that the remains of the preserved gold decoration are visually well-functioning and there is no need for additional intervention. The cooperation of these two institutions has provided more precise dating and determination of the object itself.

Key Words: Qajar helmet; kulah kud; koftgari technique; restoration; museum presentation. 